\title{
Weldability Testing of Alloy 800
}

\author{
J. F. King \\ R. W. Reed, J r.
}

\section{OAK RIDGE NATIONAL LABORATORY} OPERATED BY UNION CARBIDE CORPORATION - FOR THE DEPARTMENT OF ENERGY 


\section{DISCLAIMER}

This report was prepared as an account of work sponsored by an agency of the United States Government. Neither the United States Government nor any agency Thereof, nor any of their employees, makes any warranty, express or implied, or assumes any legal liability or responsibility for the accuracy, completeness, or usefulness of any information, apparatus, product, or process disclosed, or represents that its use would not infringe privately owned rights. Reference herein to any specific commercial product, process, or service by trade name, trademark, manufacturer, or otherwise does not necessarily constitute or imply its endorsement, recommendation, or favoring by the United States Government or any agency thereof. The views and opinions of authors expressed herein do not necessarily state or reflect those of the United States Government or any agency thereof. 


\section{DISCLAIMER}

Portions of this document may be illegible in electronic image products. Images are produced from the best available original document. 
Printed in the United States of America. Available from National Technical Information Service

U.3. Department ul Commerce

5285 Port Royal Road, Springfield, Virginia 22161

Price: Printed Copy $\$ 4.00$; Microfiche $\$ 3.00$

This report was prepared as an account of work sponsored by an agency of the United States Government. Neither the United States Government nor any agency thereof, nor any of their employees, contractors, subcontractors, or their employees, makes any warranty, express or implied, nor assumes any legal liability or responsibility for any third party's use or the results of such use of any information, apparatus, product or process disclosed in this report, nor represents that its use by such third party would not infringe privately owned rights. 
ORNL/TM-6276

Distribution

Category

$\mathrm{UC}-79 \mathrm{~b},-\mathrm{h},-\mathrm{k}$

Contract No. W-7405-eng-26

METALS AND CERAMICS DIVISION

WELDABILITY TESTING OF ALLOY 800

J. F. King and R. W. Reed, Jr.

Date Published: Apri1 1978

This

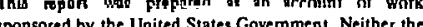
United Stotes nor the United States Department of Energy nor any of their employees, nor any of their

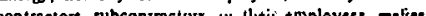
any ure cros in bity or responsibity for the acuracy, comple ar use funes of any informetion, appasus, produer or or use fulness of any information, appasalus, producr or process disclosed, or represens that his use would nor

OAK RIDGE NATIONAL LABORATORY

Oak Ridge, Tennessee 37830

operated by

UNION CARBIDE CORPORATION

for the

DEPARTMENT OF ENERGY 
THIS PAGE

\section{WAS INTENTIONALLY \\ LEFT BLANK}


CONTENTS

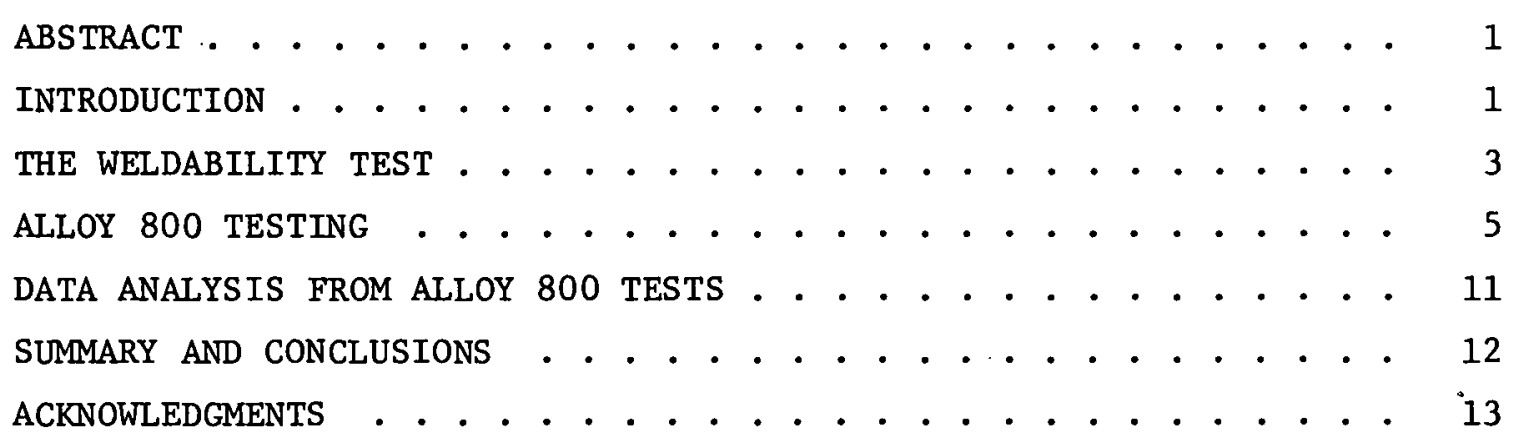




\begin{abstract}
The weldability of various heats of alloy 800 was compared by the Tigamajig hot-cracking test. This testing was conducted to determine if the test could rank the relative hot-cracking tendencies of the various heats and therefore provide a measure of weldability for future alloy 800 heats before their being assigned to nuclear component fabrication. The test accurately detected a heat that had exhibited hotcracking in the heat-affected zone of actual weldments. Neither this work nor that of other investigators has been able to specify a chemical analysis for alloy 800 that will "always" be weldable. This test can, however, be used to provide a relative measure of weldability for critical applications.
\end{abstract}

\title{
INTRODUCTION
}

Alloy 800 is a nicke1-iron-chromium alloy that has long been used as a material of construction where high-temperature strength and resistance to oxidation, corrosion, or carburization is important. Its desirable properties and satisfactory service history have prompted this alloy to be selected for several nuclear applications, including breeder reactors and high-temperature gas-cooled reactors. To fabricate the various reactor components, the alloy 800 must be welded to itself and to other alloys. Experience with alloy 800 has generally shown it to be readily weldable without major problems resulting from hot-cracking. ${ }^{1-3}$

*Work performed under DOE/RRT 189a OH103, Large-Diameter P1p1ng and Fitting Development.

${ }^{1} M$. Ward and P. L. Norman, "The Welding of Alloy $800-$ A Review," presented at the British Nuclear Energy Society Materials Conference, University of Reading, Sept. 25-31, 1974. 
Occasionally, however, a heat of alloy 800 w11l exhibit poor welding characteristics. It may be hot-cracking in the fusion zone of autogenous welds or fissuring in the heat-affected zone of welds made with filler metal addition. Previous investigations by Canonico et al. ${ }^{4}$ of commercial alloy 800 weldability showed that the presence of minor alloying elements greatly increases its susceptibility to hot-cracking over that of a "pure" ternary alloy. The scattered results in this study precluded isolating the effects of the various minor elements in commercial material. York and Flury ${ }^{5}$ investigated existing welding information and chemical analyses to determine if a composition range for alloy 800 could be proposed to improve its weldability. They concluded that insufficient information was available to permit such a recommendation for elimination of occasional cracking problems.

Accepting that one cannot now specify a composition of alloy 800 that would "always" exhibit good weldability, we considered having a test for this characteristic to be advantageous. The need for a test became greater when a plate of alloy 800 was purchased for laboratory welding development studies and was found to exhibit heat-affected zone cracking. The work reported herein contains the results of a program to develop a weldability test for alloy 800 .

${ }^{2}$ D. I. Roberts, Alzoy 800 for Nuclear Reactor Applications, GA-Al4111 (June 1977).

${ }^{3}$ Huntington Alloys, Incoloy Alloys, Bulletin 20M 2-73 T-40, International Nicke1 Co., Huntington, West Virginia.

${ }^{4}$ D. A. Canonico, W. F. Savage, W. J. Werner, and G. M. Goodwin, "Effects of Minor Additions on Weldability of Incoloy 800," pp. 68-92 in Effects of Minor Elements on the Weldability of High-Nickel Alloys (Proceedings of a Symposium), The Welding Research Council, New York, July 1969.

${ }^{5} \mathrm{~J}$. W. York and R. L. Flury, Assessment of Candidate Weld Metals for Joining Ailoy 800, WNET-119 (February 1976). 
Numerous tests for evaluating the weldability of materials have been employed. Although these tests have some merit, most have interpretation problems. The development of the Varestraint hot-cracking test offered an improved method, which can be correlated with actual fabrication behavior and permit a quantitative evaluation of weldability: ${ }^{6}, 7$ A later modification of the Varestraint test produced the sub-scale Varestraint testing device, which is commonly known as the Tigamajig. ${ }^{8}$ It maintains the desirable features of the original Varestraint test and additionally permits using smaller specimens. The Tigamajig weldability test was selected to evaluate various heats of alloy 800 , In this test, the specimen is subjected to a gas tungsten-arc spot weld thermal cycle for sufficient time to establish approximately steady-state thermal conditions. As the arc current is interrupted, an augmented strain is applied to the specimen by bending. A schematic of the Tigamajig and specimen (Fig. 1) illustrates the essentials of the test. The tangential strain on the top surface of the specimen, $\varepsilon$, is a function of specimen thickness, $t$, and bending radius, $R$, and can be calculated from:

$$
\varepsilon \approx t / 2 R
$$

Crack lengths are measured on the specimen surface in the heataffected zonc outside the weld fusion zone. In this study, the individual crack lengths are summed and the sum is designated as total crack length (TCL) at a given strain.

\footnotetext{
${ }^{6}$ W. F. Savage and C. D. Lundin, "The Varestraint Test," WeZd.

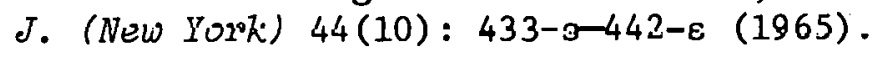

${ }^{7}$ W. F. Savage and C. D. Lundin, "Application of the Varestraint Techniques to the Study of Weldability," Weld. J. (New York) 45(11): 497-s-503-s (1966).

${ }^{8} \mathrm{G}$. M. Goodwin, The Effects of Minor Elements on the Hot Cracking of Inconel 600, Ph.D. Thesis, Rensselaer Polytechnic Institute, June 1968.
} 

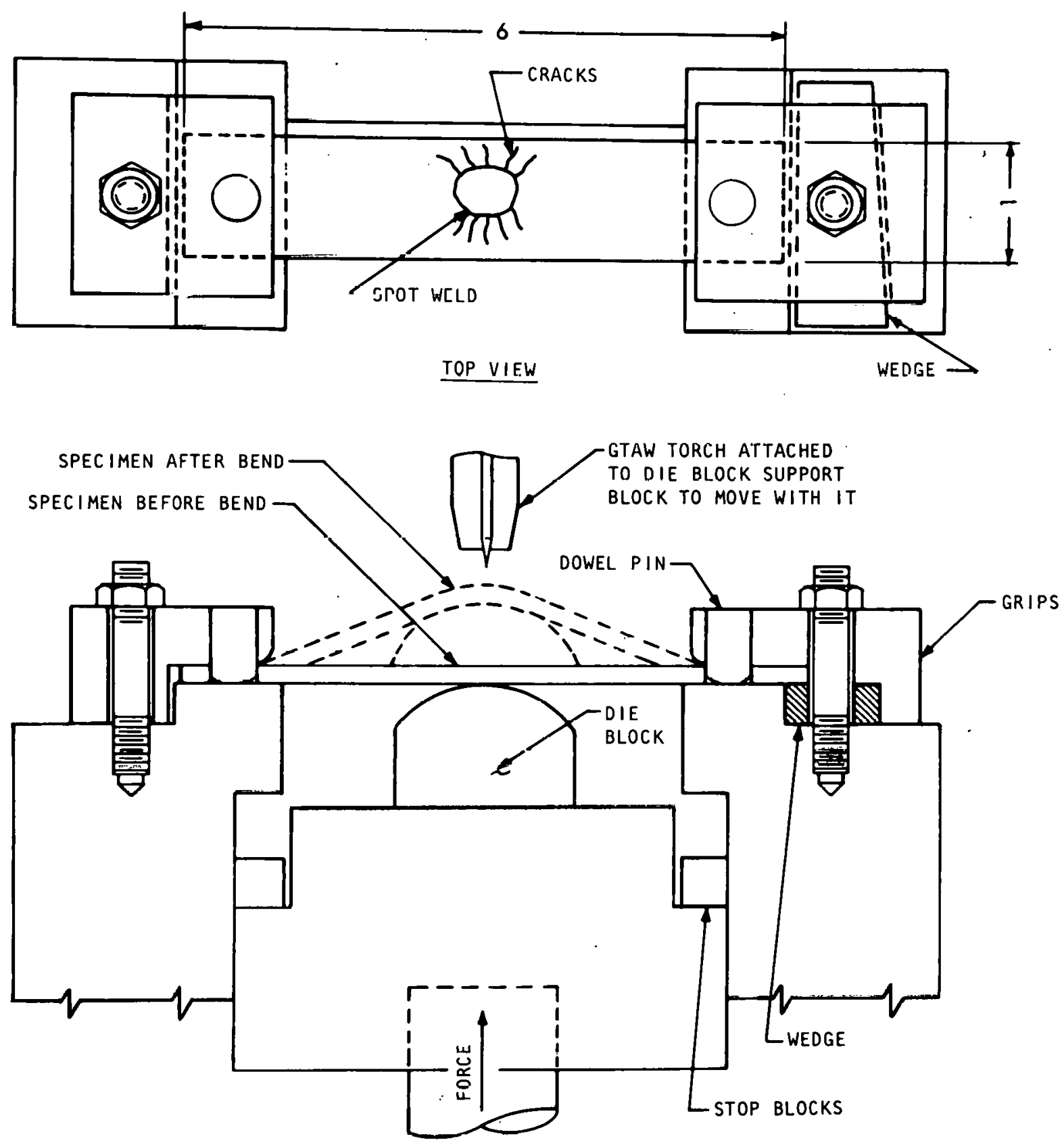

FRONT VIEW

Fig. 1. The Tigamajig Teet Device and Eecential Featureo of the Test. 


\section{ALLOY 800 TESTING}

Seven commercial heats of alloy 800 were selected for weldability testing. This material was chosen only because of its availability. It included sheet material, plates of various thicknesses, pipe, and both grades of the alloy, 800 and $800 \mathrm{H}$. Also included in this group was material from a heat that had exhibited heat-affected zone fissuring during welding (Fig. 2). Examination of the chemical analyses of this heat found it in accordance with ASTM specification B 409-74. The material heat designated as " $A$ " in the chemical analysis table (Table 1) is the crack-sensitive material. It was not apparent from these chemical analyses why this particular heat was crack sensitive.

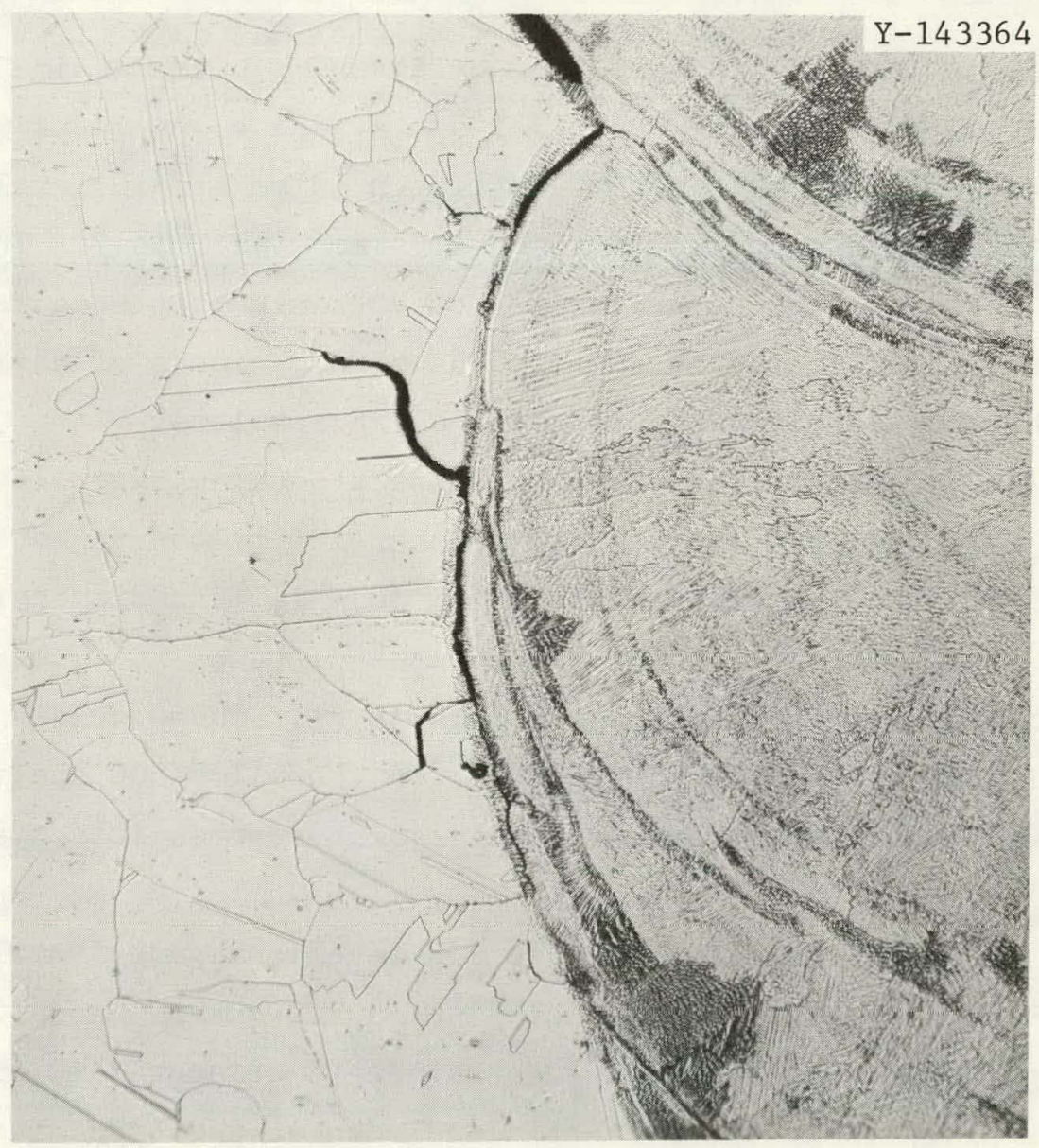

Fig. 2. Fissuring in HAZ of Alloy 800 Weldment. 50×. 
Table 1. Chemical Composition of Alloy 800 Heats Used in Weldability Test ${ }^{a}$

\begin{tabular}{ccccccccccc}
\hline & \multicolumn{10}{c}{ Content, wt \% } \\
\cline { 2 - 11 } & Heat & Mn & Fe & S & Si & Cu & Ni & Cr & Al & Ti \\
\hline A & 0.063 & 1.25 & 44.2 & 0.006 & 0.67 & 0.27 & 33.22 & 19.40 & 0.45 & 0.46 \\
B & 0.08 & 0.78 & 43.46 & 0.002 & 0.46 & 0.65 & 33.90 & 19.77 & 0.46 & 0.44 \\
C & 0.03 & 1.05 & 46.48 & 0.007 & 0.26 & 0.16 & 32.44 & 19.25 & 0.10 & 0.20 \\
D & 0.07 & 0.84 & 44.71 & 0.002 & 0.43 & 0.64 & 32.77 & 19.60 & 0.46 & 0.48 \\
E & 0.03 & 0.78 & 45.4 & 0.002 & 0.40 & 0.65 & 32.14 & 19.51 & 0.53 & 0.51 \\
F & 0.08 & 0.88 & 43.01 & 0.003 & 0.29 & 0.48 & 33.51 & 21.02 & 0.32 & 0.39 \\
G & 0.08 & 0.90 & 46.08 & 0.003 & 0.24 & 0.54 & 31.85 & 19.46 & 0.43 & 0.42 \\
\hline
\end{tabular}

$a_{\text {vendor analysis. }}$

Specimens (Fig. 3) for use in the Tigamajig hot-cracking test were prepared from the seven material heats. Five specimens were machined from each heat to permit testing at five strain levels. Specimen thickness was selected to be $4.75 \mathrm{~mm}$ (0.187 in.). This thickness permitted the establishment of approximately steady-state thermal conditions in the specimen. Thinner specimens of this material were tested, but complete melt-through often resulted.

Welding parameters were developed for producing the molten puddle by using a direct current straight polarity gas tungsten-arc welder. A weld spot approximately $10 \mathrm{~mm}$ (0.4 in.) in diameter was obtained by using a large electrode-to-work distance and accurately controlling the current and arc time (Table 2). These welding parameters made consistent arc spot welds (Fig. 4) on the alloy 800 specimens and achieved sufficient thermal stability for reproducible cracking dala.

Each heat was tested at five strain levels ranging from 1.4 to 4.9\%. As previously mentioned, this increasing strain was produced by bending the specimens around successively smaller radii (Fig. 5). The cracks produced in the heat-affected zone of the specimens (Fig. 6) were examined and measured at 50x magnification. 
ORNL-DWG 78-140
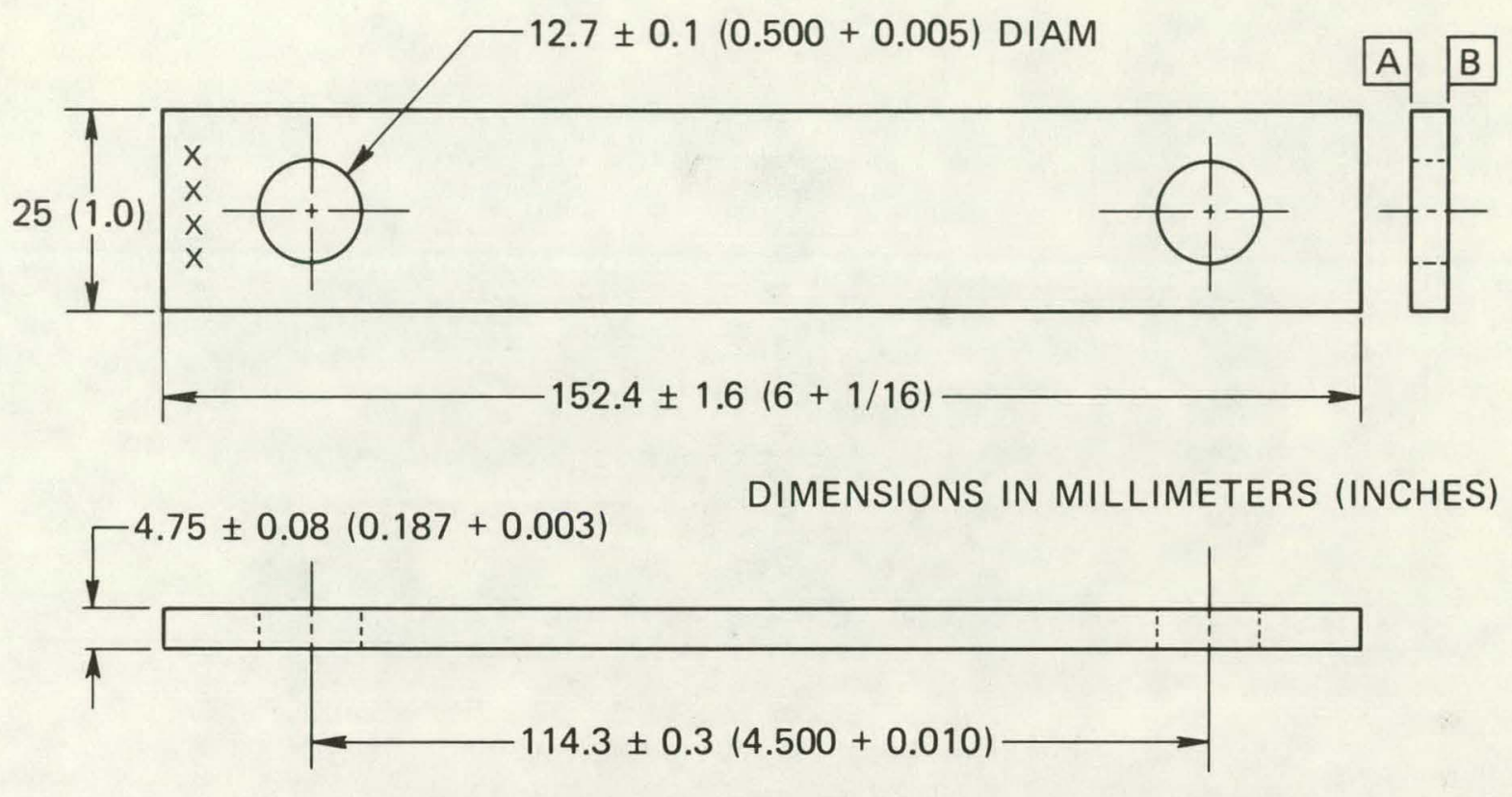

Fig. 3. Tigamajig Specimen Drawing. Notes: (1) $0.81 \mu \mathrm{m}$ (32 $\mu$ in.) finish on surfaces A and B. (2) Edges to be flat and parallel to within $0.38 \mathrm{~mm}$ (0.015 in.). (3) Surfaces A and B to be flat and parallel to within $0.13 \mathrm{~mm}$ (0.005 in.). (4) Material heat number shall be engraved or metal stamped on end of specimen as shown ( $\mathrm{xxxx}$ ).

Table 2. Welding Parameters Used in Testing the Alloy 800

\begin{tabular}{ll}
\hline Electrode-to-work distance, mm (in.) & $9.5 \pm 0.5(0.375 \pm 0.020)$ \\
Electrode type & AWS EWTH-2 \\
Electrode diameter, mm (in.) & $1.6(1 / 16)$ \\
Current, A & $75 \pm 2$ \\
Voltage, V & $12 \pm 1$ \\
Arc time, s & $40 \pm 2$ \\
Shielding gas & Argon (99.995\% pure) \\
Gas flow rate, liters/s (cfh) & $0.39 \pm 0.04(50 \pm 5)$ \\
\hline
\end{tabular}




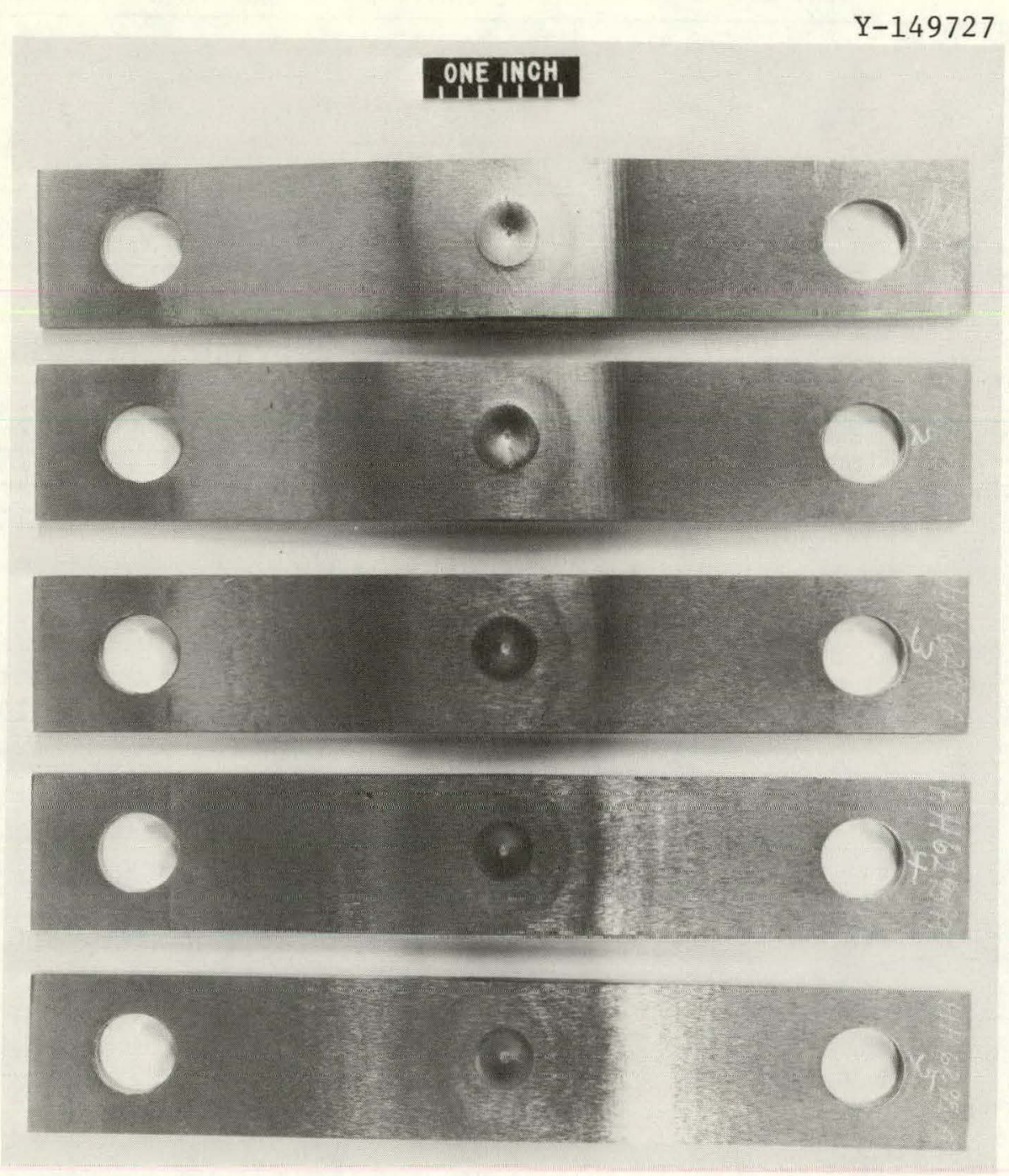

Fig. 4. A Set of Tested Tigamajig Specimens (Top View) Showing the Good Reproducibility of the Gas Tungsten-Arc Spot Weld. Scale is $25 \mathrm{~mm}$. 


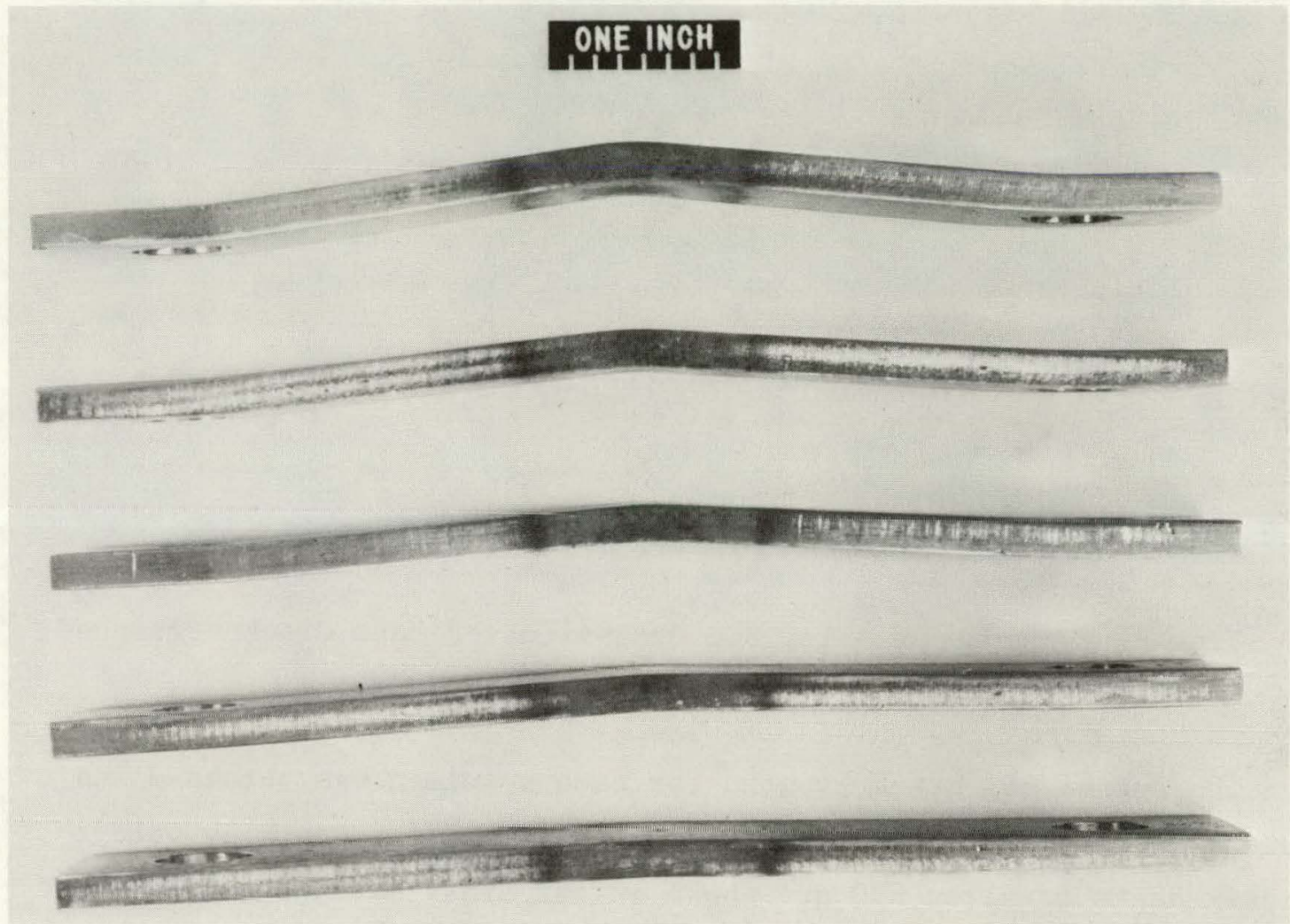

Fig. 5. A Typical Set of Five Tested Tigamajig Specimens (Side View) with Augmented Strain Increasing from Bottom to Top. Scale is $25 \mathrm{~mm}$. 
$Y-149728$

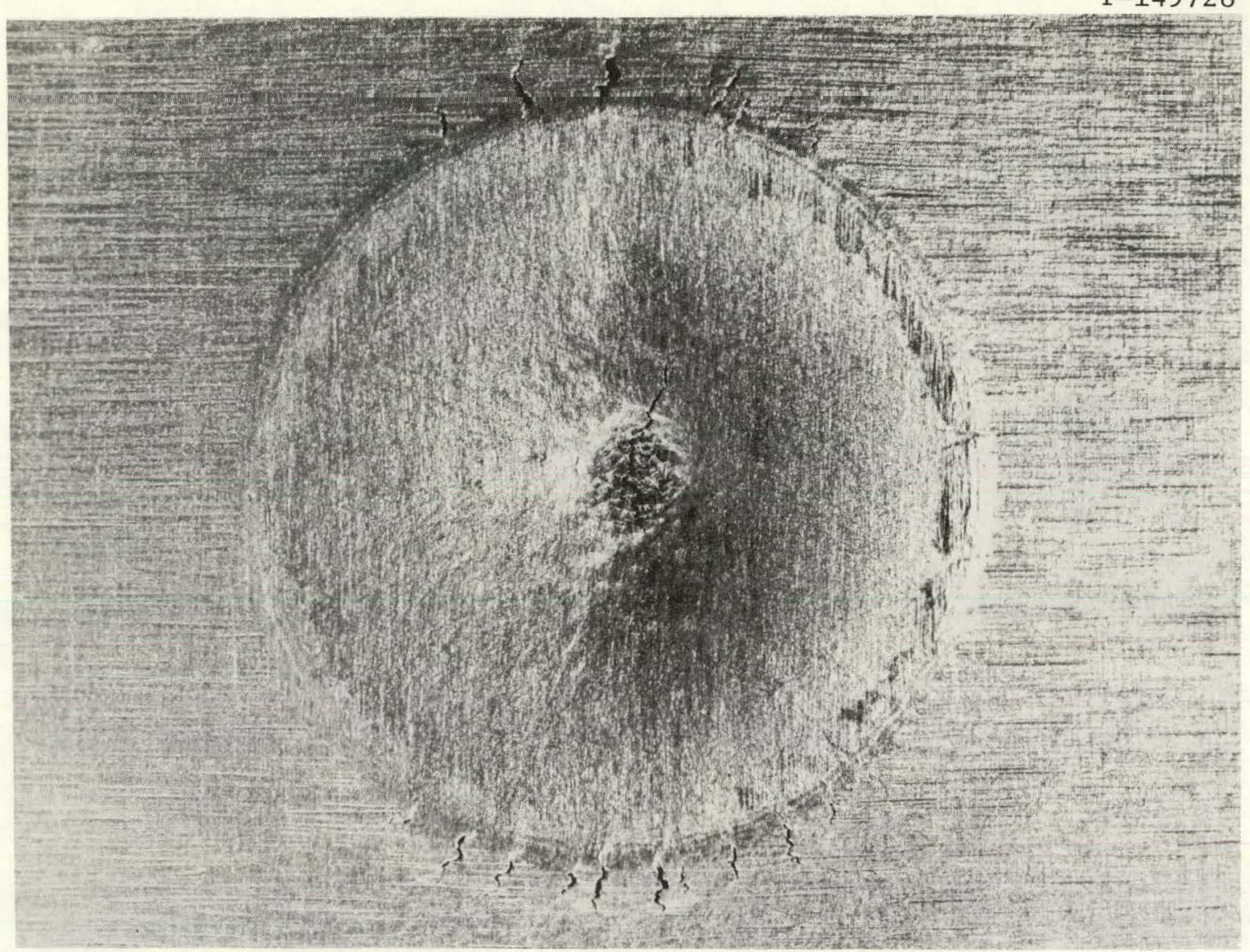

Fig. 6. Example of Alloy 800 Heat-Affected Zone Cracks Produced by the Tigamajig Test. 10x.

The sum of all crack lengths for each specimen was obtained and plotted as a function of augmented strain (Fig. 7). Cracking data for six heats of alloy 800 are shown in the cross-hatched scatter band. Heat A, shown by the dashed line, clearly exhibits a higher cracking tendency in this test than the other heats. Heat $\Delta$ had also suffered from heat-affected zone fissures during actual welding tests, while the other heats had not. Therefore, the Tigamajig test procedure can be used for determining the relative weldability of alloy 800 . 


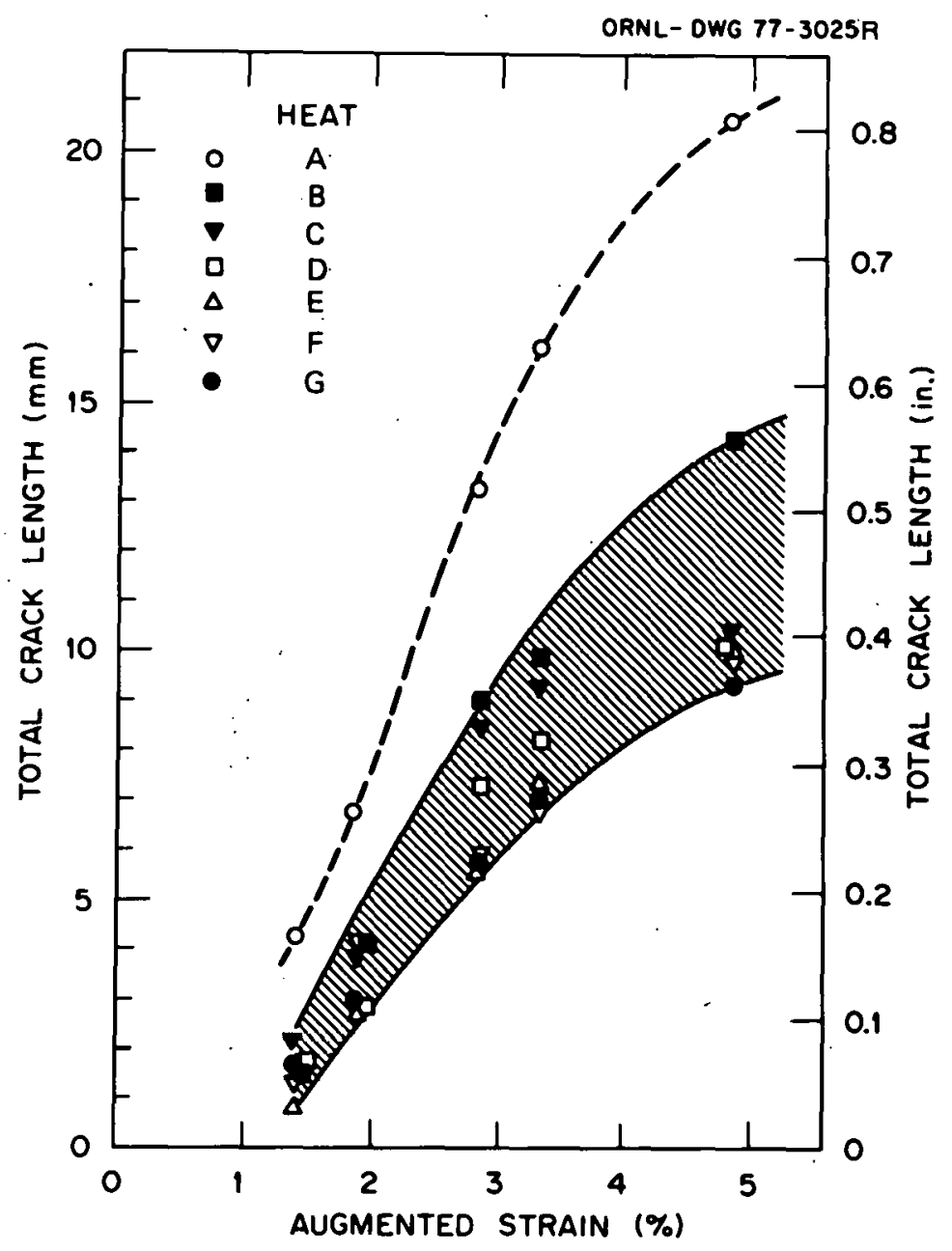

Fig. 7. T1gamajig Test Data for Alloy 800 Shows That CrackSensitive Material (Heat A) can be Identified by This Test.

\section{DATA ANALYSIS FROM ALLOY 800 TESTS}

Since the ability of the Tigamajig test to detect crack-sensitive heats of alloy 800 was established, a study ${ }^{9}$ of the correlation between crack length and chemical analysis (Table 1) was attempted. The total crack. lengths at five levels of strain for the seven heats of alloy 800 were used as a measure of hot-cracking. The correlations between total crack length. and chemical analyses were computed for each element and

${ }^{9}$ T. L. Hebble, ORNL, "Analysis of Data from Varestraint Tests on Incoloy 800," private communication to J. F. King, May 24, 1977. 
several combinations of elements. When all heats of material were considered, silicon and manganese exhibited a strong influence on hot-cracking. Omitting heat A from the analysis, however, sharply reduced the relationship between these elements and crack length. This would be expected since high levels of the two elements were present in the heat with highest cracking levels. Therefore, when a11 other heats were considered in this test, cracking was not found to depend on these elements.

No other single element or simple element-to-element ratio was found that correlated with:crack length at all strain levels. The previously reported $(\mathrm{A} 1+\mathrm{Ti}) /(\mathrm{C}+\mathrm{Si})$ ratio was found to be only a "reasonable" predictor of hot-cracking susceptibility. Other combinations of elements were considered but none were superior to this ratio.

\section{SUMMARY AND CONCLUSIONS}

The Tigamajig hot-cracking test can determine the relative weldability of alloy 800 . The test results have been verified by actual welding experience in that heat-affected zone cracking was observed in weldments of the alloy heat shown to be more crack sensitive. We could not establish an exact cracking limit at a certain strain that should not be exceeded to ensure weldability. For one material selection application, however, an upper limit of $10 \mathrm{~mm}$ total crack length at 3\% augmented strain was arbitrarily established. This was believed to be conservative, but more experimentation with alloy 800 material that exhibits higher cracking levels is necessary to determine a more accurate limit. Until such. a limit is established, sufficient test data now exist on materials with known welding behavior to permit relatively accurate predictions of weldability for unknown heats.

Correlation was poor between cracking data and the chemical analyses of the various alloy 800 heats. No single element or: combination of elements would produce suitable correlations. The ratio $(\mathrm{Al}+\mathrm{T} i) /(\mathrm{C}+\mathrm{S} i)$, however, was a reasonable predictor of 
cracking behavior compared with the others evaluated. This ratio was previously suggested by York and Flury, ${ }^{5}$ who surveyed welding data and found that heats with this ratio less than 2 had lower resistance to hot-cracking.

\section{ACKNOWLEDGMENTS}

The author wishes to acknowledge J. W. McEnerney and C. T. Liu for reviewing, S. Peterson for editing, and Julia Bishop for preparing the manuscript for publication. 
THIS PAGE

\section{WAS INTENTIONALLY LEFT BLANK}


ORNL/TM-6276

Distribution

Category

$\mathrm{UC}-79 \mathrm{~b},-\mathrm{h},-\mathrm{k}$

INTERNAL DISTRIBUTION

1-2. Centra1 Research Library

3. Document Reference Section

4-8. Laboratory Records Department

9. Laboratory Records, ORNL RC

10. ORNL Patent Office

11. C. R. Brinkman

12. J. M. Corum

13. S. A. David

14. J. H. DeVan

15. J. R. DiStefano

16. D. P. Edmonds

17. G. M. Goodwin

18. R. J. Gray

19. R. F. Hibbs

20-24. J. F. King
25. R. L. Klueh

26. W. J. McAfee

27. J. W. McEnerney

28. A. J. Moorhead

29. H. Postma

30. C. E. Pugh

31-35. R. W. Reed, Jr.

36. G. M. Slaughter

37. J. H. Smith

38. D. B. Trauger

39. R. W. Balluffi (consultant)

40. P. M. Brister (consultant)

41. W. R. Hibbard, Jr. (consultant)

42. N. E. Promise1 (consultant)

EXTERNAL DISTRIBUTION

43-44. DOE DIVISION OF REACTOR RESEARCH AND TECHNOLOGY, Washington, DC 20545

Director

45-46. DOE OAK RIDGE OPERATIONS OFFICE, P.O. Box E, Oak Ridge, TN 37830

Director, Reactor Division

Director, Research and Technical Support Division

47-333. DOE TECHNICAL INFORMATION CENTER, Office of Information Services, P.0. Box 62, Oak Ridge, TN 37830

For distribution as shown in TID-4500 Distribution Category, UC-79b (Fuels and Materials Engineering Development), UC-79h (Structural Materials Design Engineering), and UC-79k. (Components). 